\title{
The renaissance of tramways and urban redevelopment in France
}

\section{Abstract}

Tramways have made a remarkable comeback in France since the 1980s. An organization of public transport based on the decentralized administration system set up in the early 1980s has allowed local urban authorities to make their own choices to develop public transport networks in the context of automobile domination. As in many other countries, worries about fossil fuel dependency and demands concerning sustainable urban development appear as strong elements in favour of urban light rail. However, in France, tramways are not just technical solutions for traffic congestion, they have also become a symbol of a cultural mutation in urban development planning. Coupled with a national political push for a more inclusive city in social terms, tramways are the backbone of contemporary urban policies, in a French version of transit-oriented development (TOD), especially for mid-size cities.

Keywords

City planning $\bullet$ tramway $\bullet$ sustainability $\bullet$ green transportation $\cdot T O D \cdot$ France

(c) University of Warsaw - Faculty of Geography and Regional Studies

\author{
Yves Boquet \\ Department of Geography, \\ Université de Bourgogne, France \\ e-mail: yves.boquet@u-bourgogne.fr \\ Received: 3 June 2016 \\ Accepted: 15 March 2017
}

\section{Introduction}

Modal shift from private cars to public transportation is often presented as one of the pillars of sustainable mobility in cities (Ferbrache \& Knowles 2016) under the "European model". At the same time, the (re) building of cities through the reorganization of daily mobilities is at the centre of debates on urban land use and urban policies. In France, this debate is happening in the midst of a spectacular revival of tramways, which had basically disappeared in contrast to neighbouring countries, and which are now making a strong comeback in conjunction with the development of "soft" mobilities (biking, walking), efforts to set up intermodal hubs at train stations, and the search for a more harmonious city in terms of land use and social relations. Can France be considered a model for the development of urban light rail transit? (Freemark 2012)

Streetcars were major contributors to the growth of European and American cities in the late $19^{\text {th }}$ century. Alongside commuter rail, they allowed middle-class workers to move away from the crowded and expensive city centres. However, after World War I, the rise of the automobile led to a decline in the use of streetcars and the length of networks. After World War II, most French cities, as in the United States, scrapped streetcar networks completely, removing tracks from city streets, even though this trend was not followed in all European countries, as shown by the Netherlands, Germany and Central European countries.

However, the oil shocks and the beginning of the economic crisis in the 1970s, on the one hand, and the growing congestion and pollution problems in cities, on the other hand, led to a new political agenda regarding public transit. After Nantes decided to restart its tram service in 1985 , followed by Grenoble in
1987, more cities embraced light rail as a backbone of their transportation networks and as a central tool for sustainable urban development. France can now boast about a quarter of all world-wide tramway systems launched since 1980.

This raises many questions. Why this sudden revival, when the country had abandoned this transportation mode a few decades before? (Offner 1988, Larroque 1989) Is tramway better than Bus Rapid Transit? (Rabuel 2009) How are the new streetcar networks comparable to the previous networks? How are they integrated into comprehensive strategies for smart urbanism through the promotion of transit-oriented development, which uses high density urban transit corridors as the backbone of urban development, in order to minimize the use of private automobiles? How are trams related to bicycle rental schemes and the redevelopment of train stations due to the arrival of highspeed rail? What are the financing mechanisms for streetcar development and the expected outcomes of urban rail? Are the expectations of ridership met after a few years of tramway use? What should be the adequate size of the network? How does it fit with new concerns about sustainable development and a socially more inclusive city?

French tramways: from golden age to disappearance and renaissance

The rise of trams

The very first street tramways in the world opened in New York City (1832) and New Orleans (1835). American promoters brought the tramway idea to Europe. The first application in France - and in Europe - was in 1855 in Paris. This was followed 
by London in 1861, Copenhagen in 1863, and Lille in 1867. In 1873 there were already 22 lines in Paris. By the end of the $19^{\text {th }}$ century, many other French cities were served by horse trams.

The advantages of the horse tram in comparison to the horse-drawn omnibuses used in the same period were in the very low rolling resistance between wheel and rail, and thus in energy savings, more comfortable rides and increased travel speed. However, horse trams proved very limited and the restrictions of animal power were obvious: steep uphill travel was not possible, horses got tired after a while even of flat terrain and had to be replaced within a few years. Furthermore, the care of horses resulted in large personnel expenses.

More economical street railway operations were needed. Streetcar promoters soon turned to mechanical traction. Different technologies were tried: steam trams, compressed air, gas and petrol engines, cable tramways. These options faded quickly once electric traction became a possibility. After Werner von Siemens developed the first locomotive with electric traction in 1879, its quick adaptation to urban transport led to the rapid development of electric trams, which revolutionized city transit. The first electric tramways to provide public service were developed in Central and Eastern Europe: St Petersburg (1880), Berlin (1881), Vienna (1883), Frankfurt (1884), Budapest (1887). Experiments were conducted in Paris as early as 1888. The first electrified urban tram network in France was opened in Clermont-Ferrand in 1890. From 1892 onwards it spurred a boom in the construction of electric commuter railways: 11 cities in 1894, 18 in 1986, 61 in 1902,105 in 1913... (Larroque 1990). In their heyday of the early $20^{\text {th }}$ century, French trams routes totalled more than $3,400 \mathrm{~km}$ in length, with $600 \mathrm{~km}$ across Paris and its suburbs (114 lines), and $350 \mathrm{~km}$ around Lyon in the first half of the twentieth century. At that time in Paris there were up to 114 tram lines, and more than $100 \mathrm{~km}$ each in Bordeaux, Grenoble, Lille, Marseille, Nice and Strasbourg. The annual transport capacity of the trams in the 1930s was about 1.6 billion passengers, with about 700 million in Paris. Most networks were urban, but there were also some interurban lines extending from main cities to smaller towns nearby, such as St Etienne-St Chamond-Rive-de-Gier, Grenoble-Villard-de-Lans, Nice-Monaco-Menton, BayonneAnglet-Biarritz, Strasbourg-Colmar and the lines linking Lille with Roubaix and Tourcoing.

\section{The decline of trams}

This success of the tram was sometimes short-lived. In Evianles-Bains, the tram introduced in 1898 was discontinued just ten years later. In Avranches, Normandy, the electric tram introduced in 1907 stopped operating in 1914, at the start of World War I. The same thing happened in Armentières, Cambrai, CharlevilleMézières, Cherbourg, Épinal, La Bourboule, Le Puy-en-Velay, Melun and Sedan. Many of these cities - not all - were in the combat zone, but after the hostilities ended, there was no return for the trams. In fact, in the 1920s, trams also disappeared in Cannes, Elbeuf, Les Sables d'Olonne, Moûtiers, Pau and Rodez.

In larger cities, the rise of the automobile and of gasolinepowered buses led to a reduction in ridership and service, accentuated by the onset of the Great Depression in the 1930s. In Paris, the growth of the Metro underground railway, which opened in 1900, provided much faster transit across the capital city. This led to a 1929 proposal to abolish all streetcar lines, which was effective in March 1937. One after the other, French cities abandoned their streetcars: Avignon (1932), Caen (1937), Paris (1937), Orléans (1938), Reims (1939), and Amiens (1940).

The tidal wave of urban street railway decommissioning companies continued after the end of World War II. In 1960 there were only 15 systems left, and in 1971 that number was reduced to just three in Saint-Étienne, Marseille and Lille.
Networks designed half a century earlier were getting old, and suffered from overload and lack of maintenance. Public transport was not a priority for policy makers who thought at the time that the automobile was the future of mobility, as well as a big job generator (car manufacturing and servicing). When tramways had first developed, there was little traffic in the streets, but as the number of registered cars increased, traffic became denser in the rather narrow central city streets of French cities and trams were accused of causing frequent traffic jams.

Press campaigns demanded the removal of tramways. They were considered too heavy, too slow, too noisy, too rickety, too uncomfortable. They disfigured the cityscape with their overhead electric lines and their slippery tracks were dangerous to pedestrians in rainy weather. Tram networks, being no longer maintained or upgraded, were completely discredited in the public eye.

In many cases, the trolleybus was considered as a substitute, but again was discarded quite soon due to the complexity of its overhead electric power system. Only four cities still operate trolleybuses: Limoges, Lyon, Nancy and Saint-Étienne.

Diesel-fuelled buses became the dominant public transit form for those who did not drive a car. Buses were seen as a better alternative, since they were more reliable, more flexible than fixedtrack streetcars, and therefore better able to respond to changing demands in mobility, at a much lower cost of initial investment and maintenance. They did not require costly infrastructures and equipment since they just used the roadway, for which the maintenance costs were difficult to pass on to specific users.

The abolition of trams had first hit small and medium-sized towns, due to the possibility of using buses, which were cheaper to maintain than trams, in small markets. At the same time, urban areas in Germany and the Benelux modernized their tram networks with new high-capacity vehicles and invested in better tracks and sometimes underground tunnels (Cologne, Essen, Brussels) to reduce congestion at major intersections. A similar modernization of large tram networks did not occur in France (Groneck 2007).

Some authors (Muller 2000) have advanced the idea of the responsibility of the auto industry for the disappearance of trams, reminiscent of the theory of a Machiavellian conspiracy of the automobile and petroleum industries to kill American streetcar systems (Wilkins 1995, Snell, 2001, O'Toole 2012). In fact, French car manufacturers were also bus manufacturers and lobbied government authorities to limit the speed of trams to 30 kilometres per hour when buses were allowed $45 \mathrm{~km} / \mathrm{h}$. Cutthroat competition instead of complementarity and intermodal cooperation between bus companies and tram companies turned to the advantage of buses. Deprived of revenues, tram companies were not able to invest and modernize their networks, contrary to what happened in Germany, where trams were still making money.

The three remaining tram networks of France in Lille, SaintEtienne and Marseille were only residual fragments of once much larger networks, and quite different from each other. The narrow metric gauge operation of Lille, nicknamed "the Mongy" after its original engineer Alfred Mongy (1840-1914), is an interurban line with two route branches, from Lille to Roubaix and Lille to Tourcoing. In Saint-Étienne, the tram line inaugurated in 1897, also metric gauge, runs through the very centre of the city and has been able to attract enough ridership to stay in operation even as other cities were shutting down their tramways. The only standard gauge tramway of France to survive the closure was in Marseille. However, its route length shrank drastically from 178 $\mathrm{km}$ in the 1930s to only $3 \mathrm{~km}$ in 1960 . Line $\mathrm{n}^{\circ} 68$ finally closed in 2004 , as work started on a brand new network which was launched in 2007. 
Rebirth of trams

Since the early 1970 s and the often-quoted remark of then French President Georges Pompidou, "We must adapt the city to cars", city transportation policies have evolved drastically.

\section{The Cavaillé challenge}

The oil shock of 1973 and the growing problems of urban congestion in France led to a policy shift more favourable to mass public transport (Marconis 1997). While metro was favoured by Lyon and Marseille, the two largest provincial cities (1 million people) which inaugurated their respective networks in 1978, the revival of the trams in France was launched on February 27, 1975 by then transportation minister Marcel Cavaillé.

On that date, he sent a letter to the mayors of eight large cities in France (Bordeaux, Grenoble, Nancy, Nice, Rouen, Strasbourg, Toulon and Toulouse), asking them to think about the reintroduction of trams in France, citing the "need to define technical choices and implementation schedules (...) and study, as quickly as possible, solutions using mostly existing road space and requiring minimal new infrastructure, especially underground." The other component of the proposal was aimed at equipment manufacturers, who were invited to propose a common standard for a tram model adapted to new demands. This "Cavaillé challenge" was to demonstrate the feasibility of tramways and to design a possible route network. In order to get national government financing, they had until June of the same year to submit their proposals. A very short time horizon for implementation of the project (5 to 10 years) was being considered. The French government would fund half the cost of projects, and to reduce costs it teamed up with railcar maker GEC-Alsthom, which also built the high-speed TGV trains, to develop a common design standard for rolling stock.

However, this challenge was either ignored or rejected by most local decision makers, who did not want a return to this means of transport, then considered as archaic. According to witnesses, the long-time mayor of Bordeaux, Jacques ChabanDelmas, a former prime Minister of France, uttered: "I removed the tram from Bordeaux, it is not to bring it back". In fact, some cities had other plans for public transit, such as automated metros or cable car systems. Lille chose to develop the first driverless metro system in the world, the VAL, Villeneuve d'Ascq to Lille (1983), built by Matra (soon to be commercialized as Véhicule Automatique Léger - Light Automated Vehicle - to keep the original acronym). Only Grenoble agreed to build a tram.

\section{The pioneering efforts in Nantes and Grenoble}

Nantes, a large western city, was not part of the ministerial panel, but nevertheless declared its interest. It designed a network, despite the scepticism of the population and local political opposition. In 1985 Nantes became the first French city to introduce modern tramways, setting the stage for future developments. The Nantes system was conceived as having its own right-of-way route for most of the length of the lines, standard railroad gauge and overhead catenaries. The Grenoble tramway, opened in 1987, brought a major innovation with low-floor/easy access rolling stock, therefore making this mode of transport more accessible to disabled people than in Nantes, without the need to use high platforms. Other networks ( $\mathrm{T} 1$ in St Denis, a Paris northern suburban town, 1992, and Rouen, 1994) quickly adopted this standard. Grenoble was also the first French city to couple the creation of a tramway with an urban development project, linking the central train station area to the new university campus in the eastern suburbs. Strasbourg, having long considered the VAL, also coupled tram development and urban renewal within the larger framework of questioning the emphasis on cars in the city, as shown by its very bicycle-friendly policies (Mercier 2008).
Its tram was inaugurated in 1994, offering large windows and a grassy strip between the rails for a large part of the network, in order to reduce noise and also to give a symbolic green touch to its tram, another design that was followed by other cities in subsequent years.

Financing of tramway systems was provided partly (about one third) by the "versement transports" (transport tax) (Offner et al. 2002), first established in 1971 in the Paris region, then extended in 1973 to urban areas of over 300,000 people, in 1974 to areas of over 100,000, in 1982 to those of 30,000 people and finally in 1999 to those of over 10,000 . This is a tax paid to local governments in charge of public transport (AOTU, Autorité Organisatrice des Transports Urbains) by businesses of more than 9 employees, and used for the development and operation of collective passenger transport. It is estimated that trams cost 2 to 4 times less per kilometre than heavy rail underground transport (which is better suited for cities above 800,000 people), but it costs about three times more than a capacity-equivalent bus system ${ }^{1}$. Therefore, it seems that smaller towns - for example, under 100,000 people - will not find any advantage in tramways. In addition, French national urban policies require that urban areas develop Urban Mobility Plans (PDU, Plans de Déplacement Urbains) (see below) taking into account not only the topics of accessibility and social justice in transportation opportunities, but also the dimension of sustainability, under the umbrella of "Local Agendas 21". Electricpowered streetcars/tramways are the instrument of choice, even if efforts have been made to reduce the pollution of regular buses (introduction of natural gas powered vehicles). The return of the streetcar implies months of roadworks in city centres, and sometimes a complete reshuffling of bus routes.

\section{Decentralization and PDUs}

In the early 1980 s, a major decentralization process took place in France after the advent of the socialist government under President Mitterrand. Different levels of local authorities (municipalities, departments, regions) were given responsibility for the organization of public transport and urban mobility plans (PDU) became the top transportation planning tool with the 1982 LOTI Act (Loi d'Orientation des Transports Intérieurs, law on domestic transportation). The new law encouraged the development of public transport and project management was entrusted to AOTUs (Autorités Organisatrices des Transports Urbains, organizing authorities of urban transport), i.e. metropolitan districts. French metropolitan areas were to implement plans for urban mobilities, known as PDUs (Plans de Déplacements Urbains). The underlying concept was that urban transportation planning must be in a position to accommodate, and even anticipate, the city's continual pace of expansion and transformation, but also to adapt to the changes in behaviours and lifestyles. PDUs became mandatory in 1996 after the passage of a law on air (quality) and rational use of energy, nicknamed LAURE (Loi sur l'Air et l'Utilisation Rationnelle de l'Énergie, law on air and rational energy use). The June 1999 LOADDT Act (Loi d'Orientation sur l'Aménagement Durable des Territoires), known as "Loi Voynet", set in place tools for territorial projects, global strategies with environmental concerns and the development of "local development contracts". The July 1999 "Loi Chevènement" Act on inter-communality (Loi relative au renforcement et à la simplification de la coopération intercommunale) defined the structures and modes of organization for regional cooperation between municipalities. The 2000 SRU law (Solidarité et

${ }^{1}$ http://www.lvmt.fr/IMG/pdf/Cout_Production_TC_SL.pdf

${ }^{2}$ Mrs Voynet, leader of the Green Party, was at the time the Minister for Environmental Affairs in the Leftist coalition government of Socialist Prime Minister Lionel Jospin (while right-wing Jacques Chirac was president). Mr Chevènement was the Socialist Minister of the Interior, in charge of territorial planning. 
Renouvellement Urbain $^{3}$ ) made PDUs a part of general urban policy planning with the creation of SCOTs (Schémas de Cohérence Territoriale), replacing the previous SDAUs (Schémas Directeurs d'Aménagement Urbain) and giving a strong push towards the integration of urban planning and transportation policies (rail projects must be part of urban planning, all major urban projects must be organized according to existing or planned transport infrastructure), as well as efforts to reduce the social gap between richer and poorer neighbourhoods.

Three components dominate the new policies and regulations:

- a greater role given to "urban areas", redefined by the 1999 Loi Chevènement, with a council made up of officials representing all participating municipalities. The management of urban problems must be at the metropolitan scale, and efforts are made to save public funds by avoiding duplicate and separate developments in the same urban area

- a strong social bent of the SRU law, requiring, for instance, that more social housing be built in affluent municipalities at least $20 \%$ of the housing stock - to prevent a further widening of the "social gap" evoked in 1995 by president Chirac. Non-compliant municipalities could be fined.

- environmental efforts which are the background of many measures. They include policies of green sustainable transportation aimed at reducing congestion and pollution.

The ambition of PDUs, within this new institutional framework, is to ensure a sustained balance between the mobility needs of inhabitants and the protection of their health and the environment (Yerpez 1995, Frère et al. 2000, Tira \& Yerpez 2002). These plans determine, within the spatial framework of a "perimeter of urban transportation" (PTU), the overall organization of people transport, freight traffic, circulation and parking. All transportation modes are included, and the focus is on the development of alternate modes to reduce automobile dependency (Millet 2008). On-demand transport, social discounts and intermodal parking lots must be part of the transportation offer in French cities, as well as "soft" transportation modes. The PDU must balance the needs for mobility and protection of the environment, as well as strengthening social and urban cohesion. Transport, therefore, comes to occupy a central space in local public policies.

PDUs are now mandatory for urban and metropolitan areas of more than 100,000 inhabitants, they are valid for 5 years and can be modified if the spatial perimeter is changed to reflect the inclusion of new municipalities in the metropolitan area. Measures to implement include:

improving safety in all modes of transport;

reducing the share of automobile travel;

reorganizing parking on streets and in car parks;

rationalizing the transportation and delivery of merchandise,

in order to minimize the negative effects of truck parking while ensuring smooth activity for shops and businesses;

developing public transportation, with increased use of buses, and development of subway lines in larger cities or the return of streetcars in mid-size cities;

implementing integrated ticketing schemes to facilitate the daily life of transit users

- encouraging businesses and public administrations to develop Plans de Déplacements d'Entreprise (plans for corporate travel: car-sharing, limitation of parking spaces, incentives for public transport use);

- $\quad$ fostering the use of non-motorized, non-polluting modes of transportation: walking (all-pedestrian zones and streets) and cycling (Boquet 2010a, Héran 2014).

${ }^{3}$ Solidarity and Urban Renewal.
Grenelle de l'Environnement

A further impetus was given to tramways when, in 2007, freshly elected president Nicolas Sarkozy convened the "Grenelle de l'Environnement' (Grenelle Environment Summit), a major symposium to define a roadmap for France in favour of ecology, sustainable development and planning, ranging from energy production choices to farming practices. Working groups included representatives of the central government, local governments, employer organizations, trade unions, academics and nongovernmental organizations. They gathered to debate around the themes of climate change, energy, biodiversity, natural resources, agriculture, health, ecological democracy, development patterns, environmental employment and competitiveness. Their initial recommendations were presented in late September 2007 and led the government to propose to the Parliament 20 environmental policy measures to be adopted as quickly as possible. The main commitments related to low energy consumption standards in housing, the development of alternative energy resources (solar, wind), more control over agricultural inputs and a major programme of financing for high-speed rail and local green transportation (tramways and bicycle lanes). In this context, the national government would spend 2.5 billion euros to support the development of dedicated right-of-way corridors in French cities, aiming for a total of 1,800 kilometres by 2020 . A budget of $€ 810$ million was allocated in 2009 to 50 projects in 36 cities to finance starting work before the end of 2011. A second call for proposals was launched in May 2010, the state mobilizing 590 million euros to support 78 new projects, supported by 54 local governments: 45 BRT systems, 29 trams and 2 subways. Nearly $1,000 \mathrm{~km}$ of lines had already been built or were under construction by the end of 2013.

\section{French tramways as a backbone of local transportation Tramways and the urban hierarchy}

There is a rather clear logic in selecting a tramway. Looking at all of the 42 French metropolitan areas of more than 150,000 people outside of the Paris area, we can observe that the larger ones have subway systems complemented with tramways, and the smaller ones are relying mostly on buses. Exceptions are few: Rennes, with barely 400,000 people, has chosen the VAL system and may be the smallest city in the world boasting a subway, while Aix-en-Provence, the same size, has just buses. The adequate size for tramways appears to be in the 200,000 to 500,000 people range, which is the size of many regional capitals $^{4}$ in France (Caen, Clermont-Ferrand, Dijon, Grenoble, Montpellier, Orléans, Rouen). Besançon is at the lower end of this threshold (below 200,000), with a tram, while Amiens, the same size, has no trams. Mediterranean cities seem less inclined to the development of trams, since Toulon, Aix-en-Provence, Cannes, Perpignan and Valence are larger than some tram cities, and Marseille has not redeveloped a large network. In south-eastern France, only Montpellier (Mills 2001) has really embraced the tram. More densely populated areas also seem to be more attractive for tram development, despite the counter-example of Cannes. Rennes stands out again by having a metro system serving one of the least densely populated of the 42 large regional cities.

\section{Choosing the tram: urban politics and urban policies}

Contrary to old tram lines which were sharing space with other vehicles, modern tramways are built on a specific right-ofway route ("transport en commun en site propre"), often taking space previously occupied by car lanes. Therefore, developing a streetcar system is an act of courage for many local officials who may have to face the anger of motorists (Demongeot 2011,

${ }^{4}$ Some cities (Caen, Clermont-Ferrand, Grenoble, Montpellier) lost this status in 2016 with the regrouping of regions 


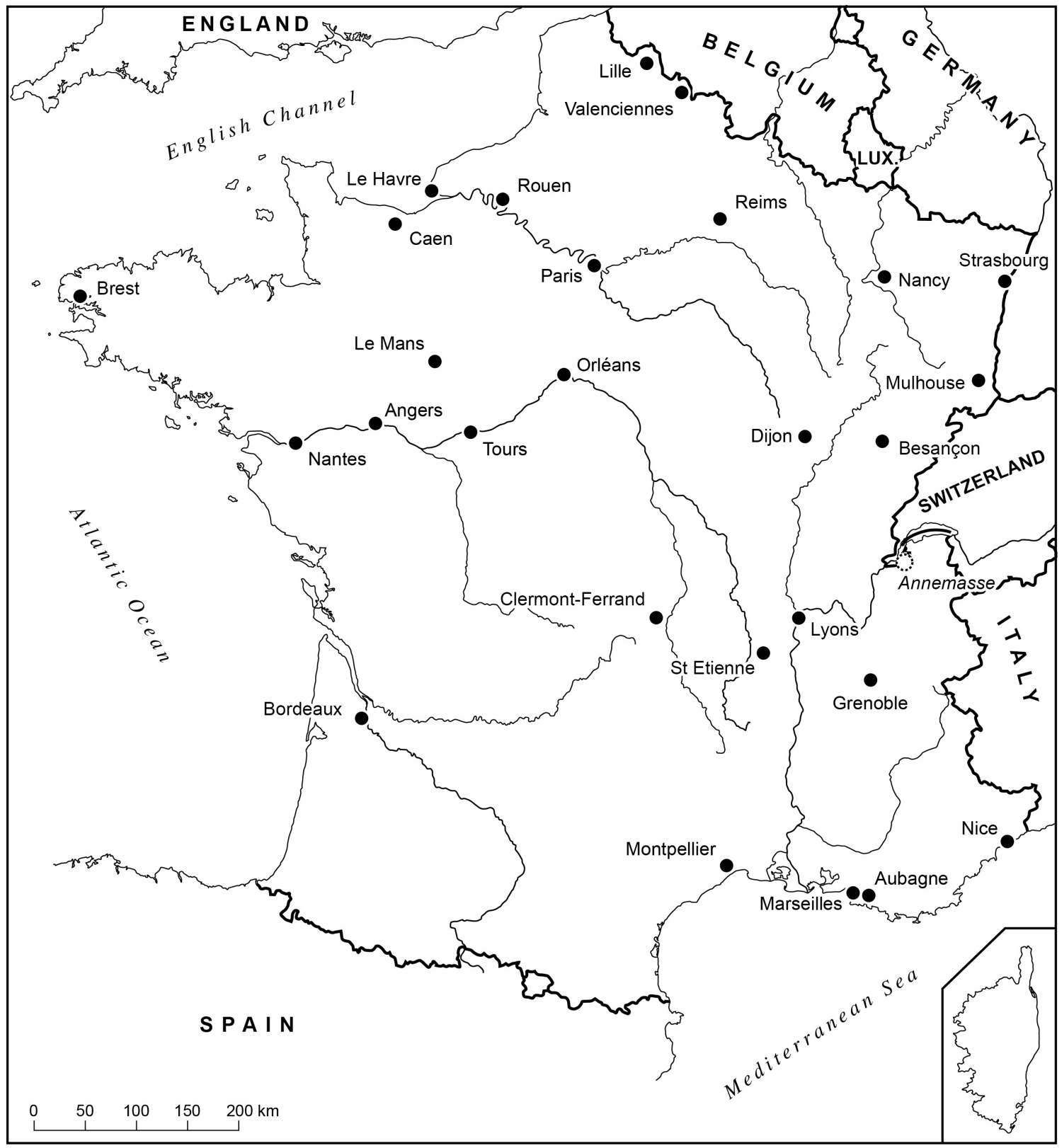

Figure 1. French cities with tramways

Design V. Lahaye based on author's sketch

Wolf 2012). In most cases, left-leaning municipal governments, often supported by the Green Party in local coalitions, have implemented tramway revival schemes. However, some mayors on the right side of the political spectrum have also championed tramways in their cities (Alain Juppé in Bordeaux). In several cities (Nantes, Strasbourg, Dijon, Orléans, and most recently Toulouse), the local political debates have focused heavily on tramways and their costs.

The intensity of the focus on tramways is such that, in the 1990 s and 2000s, having or not having a tram became the marker of a dynamic conurbation, the symbol of its commitment to modernity and sustainability (Allemand, Ascher \& Lévy, 2005). Many election campaigns have put it at the centre of the debate, often pitting pro-tramway left-leaning candidates vs. right-leaning candidates championing the rights of motorists and the virtues of the bus service, with clashes also arising linked to the cost of tram implementation (Carmona 2001).

When a city chooses trams, it also chooses to fight the automobile lobby. It is a strong political statement, and many municipal elections have been fought on pro- and countertramway debates. Traffic separation on most of the course allows trams to reach a speed of up to 50 kilometres per hour, and to keep schedules as regular as one tram every two minutes at peak hour while remaining within the margins of safety. In order to ensure this quality service provided by trams, there is the calculated risk of creating car traffic difficulties, unless motorists find it in their interests to switch to tram mode for travel within the city. Therefore, a careful design of the route is necessary, and negotiations are needed to increase the acceptance of the tram by its early opponents (Rudolf and Hamman 2011). 
Typology and topology of the French tram networks

Not only are trams running largely on dedicated right-ofway routes, the lines, although fewer, are longer than they were in previous developed networks. They tend to cross the entire urban area, and to serve the major traffic generating places in the city: train stations, universities, stadiums, convention centres, hospitals, public housing projects, entertainment venues, shopping centres and office parks. In Strasbourg, the tram system also serves the European Parliament building. In order to increase the ridership potential, many lines follow a complicated route, not always in a straight line, but peppered with many sharp turns leading to a slower speed overall (Héran 2009, Zembri 2012).

Several cities have built only one line (Brest, Nice, Toulouse), many have two or three. In several cities, tram lines use a common segment in the centre of town before separating outside the core area. It may be in the shape of a Y (Besançon, Le Havre, Lille, Mulhouse, Valenciennes) or an X (Caen, Dijon), with some combinations (Rouen). In Nantes and Orléans, lines intersect at just one central point. The most elaborate networks, in terms of a combination of multiple intersections and shared segments, are found in Grenoble, Lyon, Montpellier and Strasbourg. The Paris area (Prudhomme et al. 2008) is quite different, since the lines are not interconnected, appearing as isolated segments

The average distance between tram stations is about $540 \mathrm{~m}$, with extremes in Valenciennes $(704 \mathrm{~m})$ and Saint-Étienne (308 $\mathrm{m})$, where the network still uses the century-old scheme, although the rolling stock has been modernized. The dominant providers of tramway vehicles are the French Alsthom and Canada-based Bombardier. These two companies are also in fierce competition for the provision of regional trains operated by SNCF. In a few cities, Italian, German and Spanish manufacturers have been selected. There was an interesting team-up of two cities, Brest and Dijon, to pool their purchase of trams, in order to reduce unit costs. Since Alsthom delivered some vehicles in Brest colours quicker, while Dijon was faster in building its rail network, the first tests of rolling material in Dijon were done with Brest-bound material.

All new lines are of standard gauge, $1435 \mathrm{~mm}$, with only the old lines in Lille and Saint-Étienne running new cars on metric track. In Caen, Clermont-Ferrand and Nancy, the technical choice has been to use tyre-equipped cars guided by rail (Lohr's "tram on tyres"), in a crossbreed technology between trams and trolleybuses. Caen is planning to convert to regular track tramway in the coming years. Most French trams have a capacity of $180-250$ passengers, which is equivalent to 2 or 3 articulated buses (with one driver). Tramway units are $30-40 \mathrm{~m}$ in length, usually made up of 5 to 7 modules. Paris' line T2 is the only one to operate double-units (capacity 440).

Most cities, except Brest, Clermont-Ferrand, Marseille and Toulouse, offer a tram service to the main train station. In Lyon, Orléans and Reims, trams serve two train stations. In the specific case of Paris, there is no service to the major central stations, since the Paris tram runs on a peripheral route and most lines are in fact in the suburbs. Universities are well served, with a number of routes offering several stops across campuses, such as in Bordeaux, Dijon, Grenoble, Orléans and Strasbourg. Stadiums are not always in use, but when there is a game, the tram service helps to ferry spectators in Bordeaux, Dijon, Montpellier, Nantes, Reims and Strasbourg. Lyon is the only city where the airport is served by tramway, and in the Paris suburbs the major CBD of La Défense is the end station of one line.

The use of trams seems to vary markedly from city to city. Networks in Lille and Toulouse are smaller than in much less populated areas, and their ridership appears weak, in one case because it does not serve the city centre (Toulouse), in the other case because the automatic second metro line parallels the course of the renovated Mongy for a particular stretch. In
Valenciennes, the relatively long distances to reach a tram station may be a factor in the low traffic loads, the lowest of any city. On the contrary, Dijon, relative to its population size, has embraced the tram, since the daily ridership is equivalent to half the population of the city itself and one third of its urban area. The busiest trams, relative to the size of their networks, both in kilometres and number of stations, are found in Nice (one line only) and Strasbourg (six lines). The latter city is obviously in tune with German and Swiss attitudes towards trams. Lyon, France's second city, has a relatively modest level of tram use, given that it also has a good subway system.

Four major groups run the French tramway systems: Keolis (largely controlled by the SNCF national railway company), RATP (the Paris metro and bus company), Transdev (majority owned by government-controlled Caisse des Dépôts et Consignations) and Veolia transport, which recently merged with Transdev to become the largest European company for public transport. All these companies have extended their reach in the development and management of public transit systems across the world, from Sweden to Australia and Morocco to Hong Kong.

French tramways as a tool for urban planning

The strong bond created by the SRU law between transport planning and urban planning therefore reinforces the success of the modern French tramway. This success deserves to be analysed. The tramway is of course, first and foremost, a transport tool and provides an appropriate response to demands in capacity, service speed and comfort. It also fits within the broad "sustainable mobility" policy advocated by the LAURE Act. With its dedicated right-of-way routes, well-defined boarding/alighting platforms, and its priority at intersections, it has imposed its presence on the city and the street, especially in comparison to automobiles (Laisney 2001). The installation of the tram is seen as an opportunity for cities to redefine their projects in terms of urban planning and land use areas by rehabilitating and restructuring the urban fabric: reorganization of residential areas, recreational and work zones, reconquering the urban space, downtown revitalization, renovation of facades, and so on.

A new image for the city

The tram, while it does more than the bus, is not a subway. It is open to the city and visible from the city. Tramways interact with the city in many different ways: they are open to the city and visible from the streets.

Architects, designers and landscapers have seized this opportunity and endeavoured to leverage this visibility in order to give a face to the abstract concept of sustainable development, whose benefits can be seen only in the very long term. The tramway gives an impression of immediate environmental improvement: silent ride, no direct air pollution, tree planting alongside the tramway routes and grassy right-of-way passages. It is the immediate image of a sustainable city.

The reconquering of public space in cities where the tram had been absent for twenty or thirty years has led to the demolition and complete rebuilding of many streets. While this has meant sometimes a many-month-long nightmare in terms of traffic rerouting and impaired access to shops, municipalities are taking advantage of tramway work to redesign their town centre streets. It is a unique opportunity to restore, at least locally, urban landscapes which had been dominated and often disfigured by cars: the removal of barrier effects, the redistribution of traffic, greater consideration of pedestrians and cyclists, and the architectural treatment of stations. Tram implementation helps to rebuild quality city streets, from facade to facade. Nantes led the way with the radical transformation of the "Cours des cinquante otages", where eight lanes of car traffic were replaced by a planted 
Table 1. French tram systems currently in operation (as of January 2015), in alphabetical order

\begin{tabular}{|c|c|c|c|c|}
\hline Urban area & Rolling stock & $\begin{array}{c}\text { Specific } \\
\text { characteristics }\end{array}$ & Network topology & $\begin{array}{l}\text { Major urban nodes } \\
\text { served }\end{array}$ \\
\hline $\begin{array}{l}\text { Angers } \\
(2011)\end{array}$ & Alsthom Citadis 302 & & Single line & Train station, University \\
\hline $\begin{array}{c}\text { Aubagne } \\
(2014)\end{array}$ & Alsthom Citadis Compact & & Single line & Train station \\
\hline $\begin{array}{c}\text { Besançon } \\
(2014)\end{array}$ & Urbos 3 (CAF, Spain) & & Y-shaped & Train station, University \\
\hline $\begin{array}{l}\text { Bordeaux } \\
(2003)\end{array}$ & Alsthom Citadis 302, 402 & & 3 line intersections & $\begin{array}{c}\text { Train station, University, } \\
\text { Stadium }\end{array}$ \\
\hline $\begin{array}{l}\text { Brest } \\
(2012)\end{array}$ & Alsthom Citadis 302 & & Single line & \\
\hline $\begin{array}{c}\text { Caen } \\
\text { (2002) }\end{array}$ & Bombardier TVR / GLT & Rubber tyres * & Shared central corridor & Train station, University \\
\hline $\begin{array}{l}\text { Clermont-Ferrand } \\
(2006)\end{array}$ & Translohr & Rubber tyres & Single line & \\
\hline $\begin{array}{l}\text { Dijon } \\
(2012)\end{array}$ & Alsthom Citadis 302 & & Shared central corridor & $\begin{array}{c}\text { Train station, University, } \\
\text { Stadium }\end{array}$ \\
\hline $\begin{array}{c}\text { Grenoble } \\
(1987)\end{array}$ & Amlsthom TFS \& Citadis 402 & & $\begin{array}{c}2 \text { shared corridors } 4 \text { line } \\
\text { intersections }\end{array}$ & Train station, University \\
\hline $\begin{array}{l}\text { Le Havre } \\
\text { (2012) }\end{array}$ & Alsthom Citadis 302 & & Y-shaped & Train station, University \\
\hline $\begin{array}{l}\text { Le Mans } \\
(2007)\end{array}$ & Alsthom Citadis 302 & & Shared central corridor & Train station, University \\
\hline $\begin{array}{l}\text { Lille - Roubaix - } \\
\text { Tourcoing (1909) }\end{array}$ & Ansaldo Breda (Italy) & 1 metre gauge & Y-shaped & Train station \\
\hline $\begin{array}{l}\text { Lyon } \\
(2001)\end{array}$ & $\begin{array}{l}\text { Alsthom Citadis 302, 402, } \\
\text { Stadler Tango (Switzerland) }\end{array}$ & & $\begin{array}{c}3 \text { shared corridors, } 3 \text { line } \\
\text { intersections }\end{array}$ & $\begin{array}{l}2 \text { train stations, } \\
\text { University, Airport }\end{array}$ \\
\hline $\begin{array}{l}\text { Marseille } \\
(1893)\end{array}$ & Bombardier Flexity Outlook & & 1 line intersection & Port \\
\hline $\begin{array}{l}\text { Montpellier } \\
(2000)\end{array}$ & Alsthom Citadis 301, 302, 402 & & $\begin{array}{c}\text { line intersections, } 3 \text { shared } \\
\text { segments, } 1 \text { loop line almost } \\
\text { complete }\end{array}$ & $\begin{array}{c}\text { Train station, University, } \\
\text { Stadium }\end{array}$ \\
\hline $\begin{array}{l}\text { Mulhouse } \\
(2006)\end{array}$ & $\begin{array}{l}\text { Alsthom Citadis } 302 \& \\
\text { Siemens Citado }\end{array}$ & & $\begin{array}{c}\text { Y-network } 3 \text { lines + tram- } \\
\text { train }\end{array}$ & Train station \\
\hline $\begin{array}{l}\text { Nancy } \\
(2000)\end{array}$ & Bombardier TVR / GLT & Rubber tyres & Single line & Train station \\
\hline $\begin{array}{l}\text { Nantes } \\
(1985)\end{array}$ & $\begin{array}{c}\text { Alsthom TFS, Adtranz Incentro } \\
\text { (Germany), Urbos } 3 \text { (CAF, } \\
\text { Spain) }\end{array}$ & & $\begin{array}{l}4 \text { lines, } 1 \text { hub, } 1 \text { shared } \\
\text { segment }\end{array}$ & $\begin{array}{c}\text { Train station, University, } \\
\text { Stadium }\end{array}$ \\
\hline $\begin{array}{c}\text { Nice } \\
(2007)\end{array}$ & Alsthom Citadis 302, 402 & & Single line & Train station, University \\
\hline $\begin{array}{l}\text { Orléans } \\
(2000)\end{array}$ & Alsthom Citadis 301 & & 1 line intersection & 2 train stations, University \\
\hline $\begin{array}{l}\text { Paris - lle-de- } \\
\text { France } \\
\quad(1992)\end{array}$ & $\begin{array}{c}\text { Alsthom TFS, Alsthom Citadis } \\
\text { 302, 402, Siemens Avanto } \\
\text { S70, Translohr STE3, STE6 }\end{array}$ & $\begin{array}{l}2 \text { rubber tyre } \\
\text { tramway lines }\end{array}$ & $\begin{array}{l}9 \text { separate lines } 1 \text { loop } \\
\text { around Paris to be } \\
\text { completed, other lines in } \\
\text { suburbs }\end{array}$ & $\begin{array}{c}\text { No major train station, } \\
1 \text { suburban university, } \\
\text { service to La Défense } \\
\text { CBD }\end{array}$ \\
\hline $\begin{array}{l}\text { Reims } \\
(2011)\end{array}$ & Alsthom Citadis 302 & & Shared central corridor & $\begin{array}{c}2 \text { train stations, } \\
\text { University, Stadium }\end{array}$ \\
\hline $\begin{array}{l}\text { Rouen } \\
(1994)\end{array}$ & Alsthom Citadis 402 & & $\begin{array}{l}\text { Shared central corridor for } 3 \\
\text { lines Y-shaped at both ends }\end{array}$ & Train station, University \\
\hline $\begin{array}{c}\text { Saint-Étienne } \\
\text { (1881) }\end{array}$ & Alsthom Vevey TFS & 1 metre gauge & 2 shared central corridors & Train station, University \\
\hline $\begin{array}{l}\text { Strasbourg } \\
(1994)\end{array}$ & $\begin{array}{l}\text { Bombardier Eurotram, } \\
\text { Alsthom Citadis } 403\end{array}$ & & $\begin{array}{c}\text { Several shared central } \\
\text { corridors, one } 5 \text { line hub, two } \\
4 \text { line hubs, two } 3 \text { line hubs }\end{array}$ & $\begin{array}{l}\text { Train station, University, } \\
\text { European parliament, } \\
\text { Stadium }\end{array}$ \\
\hline Toulouse (2010) & Alsthom Citadis 302 & & Single line & \\
\hline Tours (2013) & Alsthom Citadis 402 & & Single line & Train station, University \\
\hline $\begin{array}{l}\text { Valenciennes } \\
(2006)\end{array}$ & Alsthom Citadis 302 & & Y-shaped & Train station, University \\
\hline
\end{tabular}

( ${ }^{*}$ to be abandoned for conventional rail)

Table compiled by author from the respective transport system websites. 
MISCELLANEA GEOGRAPHICA - REGIONAL STUDIES ON DEVELOPMENT

Vol. $21 \cdot$ No. 1 • 2017 • pp. 5-18 • ISSN: 2084-6118 • DOI: 10.1515/mgrsd-2017-0005

Table 2. Tramway network data (ranking according to length of network)

\begin{tabular}{|c|c|c|c|c|}
\hline & Number of lines & Number of stations & Network length (km) & Average distance $(\mathrm{m})$ \\
\hline Paris / lle-de-France & 9 & 181 & 103.8 & 573 \\
\hline Lyon & 6 & 99 & 66.3 & 670 \\
\hline Montpellier & 4 & 83 & 56 & 675 \\
\hline Bordeaux & 3 & 89 & 45.4 & 510 \\
\hline Nantes & 3 & 82 & 41.3 & 504 \\
\hline Strasbourg & 6 & 72 & 40.7 & 565 \\
\hline Grenoble & 5 & 71 & 36 & 507 \\
\hline Valenciennes & 2 & 48 & 33.8 & 704 \\
\hline Orléans & 2 & 49 & 29.3 & 598 \\
\hline Dijon & 2 & 35 & 19 & 543 \\
\hline Le Mans & 2 & 35 & 18.9 & 540 \\
\hline Lille - Roubaix - Tourcoing & 2 & 36 & 17.5 & 486 \\
\hline Mulhouse & 3 & 29 & 16.2 & 559 \\
\hline Clermont-Ferrand & 1 & 34 & 15.9 & 468 \\
\hline Caen & 2 & 34 & 15.7 & 462 \\
\hline Tours & 1 & 29 & 15.5 & 534 \\
\hline Rouen & 1 & 31 & 15.1 & 487 \\
\hline Besançon & 2 & 31 & 14.5 & 468 \\
\hline Toulouse & 1 & 24 & 14.3 & 596 \\
\hline Brest & 1 & 28 & 14.3 & 511 \\
\hline Le Havre & 2 & 23 & 13 & 565 \\
\hline Angers & 1 & 25 & 12.3 & 492 \\
\hline Saint-Étienne & 3 & 38 & 11.7 & 308 \\
\hline Marseille & 2 & 28 & 11.5 & 411 \\
\hline Reims & 1 & 23 & 11.2 & 487 \\
\hline Nancy & 1 & 28 & 11.1 & 396 \\
\hline Nice & 1 & 22 & 9.2 & 418 \\
\hline Aubagne & 1 & 7 & 2.8 & 400 \\
\hline TOTAL & 71 & 1,314 & 712.3 & 542 \\
\hline
\end{tabular}

Table compiled by author from the respective transport system websites

Table 3. Tramway service data (ranking according to daily ridership)

\begin{tabular}{|c|c|c|c|c|}
\hline & Service provider & Daily passengers & Passengers / km & Passengers / station \\
\hline Paris / lle-de-France & RATP-SNCF & 700,000 & 6,744 & 3,867 \\
\hline Strasbourg & Keolis / CTS & 300,000 & 7,371 & 4,167 \\
\hline Nantes & Transdev / Semitan & 285,000 & 6,904 & 3,477 \\
\hline Bordeaux & Keolis / TBC & 282,000 & 6,211 & 3,169 \\
\hline Montpellier & Transdev / TAM & 282,000 & 5,036 & 3,398 \\
\hline Lyon & SNCF / Sytral & 250,000 & 3,771 & 2,525 \\
\hline Grenoble & Transdev / Semitag & 210,000 & 5,842 & 2,962 \\
\hline Nice & Veolia / Lignes d'Azur & 90,000 & 9,783 & 4,091 \\
\hline Dijon & Keolis / Divia & 84,000 & 4,421 & 2,400 \\
\hline Orléans & Keolis / TAO & 71,000 & 2,423 & 1,449 \\
\hline Rouen & Transdev / TCAR & 67,000 & 4,437 & 2,161 \\
\hline Mulhouse & Transdev / Solea & 60,000 & 3,704 & 2,069 \\
\hline Clermont-Ferrand & $\mathrm{T} 2 \mathrm{C}$ & 57,000 & 3,585 & 1,676 \\
\hline Marseille & RTM & 53,000 & 4,609 & 1,893 \\
\hline Saint-Étienne & Transdev / STAS & 53,000 & 4,530 & 1,395 \\
\hline Le Havre & Transdev / Lia & 50,000 & 3,846 & 2,174 \\
\hline Le Mans & Keolis / Setram & 48,000 & 2,540 & 1,371 \\
\hline Reims & Transdev / Mars & 45,000 & 4,018 & 1,957 \\
\hline Tours & Sitcat & 45,000 & 2,903 & 1,552 \\
\hline Nancy & Transdev / Stan & 41,000 & 3,694 & 1,464 \\
\hline Caen & Keolis /Twisto & 39,000 & 2,484 & 1,147 \\
\hline Brest & Keolis / Bibus & 35,000 & 2,488 & 1,250 \\
\hline Angers & Keolis / Irigo & 34,500 & 2,805 & 1,380 \\
\hline Valenciennes & Transdev / Transvilles & 33,000 & 976 & 688 \\
\hline Besançon & Transdev / Gingko & 32,000 & 2,207 & 1,032 \\
\hline Lille-Roubaix-Tourcoing & Keolis / Transpole & 32,000 & 1,829 & 889 \\
\hline Toulouse & Tisséo & 21,000 & 1,469 & 875 \\
\hline
\end{tabular}

Computed by author from operating company data 
tree esplanade for the tram and just two lanes for cars (Peyon 2003). Grenoble followed suit with the elimination of underpasses and the planting of grass alongside the tramway tracks.

Shop owners, initially worried about losing their motorized customers, are realising that an appeased street environment can benefit them. Property owners can expect a substantial increase in the value of real estate, both commercial and residential. A high quality of urban integration is a must to overcome public reluctance to new infrastructures in the urban environment. Single overhead electric wires are more discreet than railway-style catenaries, and high quality materials generate more respectful places. The rue Nationale in Tours is paved in white stone, while slate covers the station floors in Angers. Strategic locations benefit from a new layout that reinforces their appeal, for example in Angers (Ralliement), Brest (rue de Siam), Clermont-Ferrand (Place de Jaude), Dijon (Place Darcy and Place de la République, the two main nodes of bus/tram intermodal connection), Le Havre (Boulevard de Strasbourg/avenue Foch), Nice (Place Masséna), and Orléans (Place de l'Etape).

A singular phenomenon of the past 30 years is the emergence of a "French school of trams" based on the collaboration of urban and transport planners with designers, landscape architects, artists and architects. As early as the first modern tram systems in Nantes and Grenoble, there was a deliberate effort to enhance urban landscapes and highlight the scenic aspect of tramways, with careful attention to the vehicles' design and the immediate surroundings of the line. Everywhere possible, the track corridor is covered with grass, both to reduce by a few decibels the noise generated by the wheel/rail contact, and to highlight the "green" (ecological) side of the tramway.

Several tramway projects have included cultural works, both to enhance the city's image and to win popular approval of the public spaces transformed by the tramway (Redondo 2015). Some stations in Rouen, Mulhouse, Nice and Paris include contemporary artwork. In Mulhouse, Daniel Buren has proposed the installation of a pair of arches to signal each station and create a sense of continuity on the tramway. Strasbourg's "Homme de Fer" tram station, a major node in the city's network, has become famous for its unique, iconic design.

The sleek and sometimes colourful design of new vehicles, their quiet ride, their low-floor allowing easy access for elderly people and push chairs, have contributed to making them a powerful element of urban promotion as vectors of an image of modernity and ecology (Redondo 2012). Montpellier hired designers Elisabeth Garouste and Mattia Bonetti to give identity to its trams: white seagulls flying on a rich blue background for Line 1, multicoloured flower beds decorating the whole trains of Line 2 . For Lines 3 and 4, the eccentric mayor of Montpellier Georges Frêche hired famed designer Christian Lacroix, who continued in the same vein: following on from the air and earth that inspired Lines 1 and 2 , he offered a water theme (fish, octopus and sea monsters) for Line 3 and a fire theme for Line 4 (sun rays). Mulhouse, following a public vote, chose Spanish graphic designer Peret to give the tram a sunny look, with a yellow body and red markings, and Aubagne chose artist Hervé Di Rosa to decorate their tramways. Cities have tried to get away from simple white exteriors and have adopted distinctive liveries for their trams: in Dijon, the colour evokes Burgundy wines, Orléans' tramway cars are gold, the trams in Reims, designed by Franco-Swiss Ruedi Baur, each have a different colour (pink, green, yellow) but their "face" is in the shape of a glass of Champagne, in Le Havre geometrical motives on a cream background echo the surrounding urban landscape of the city rebuilt after WWII by modernist architect Fernand Pouillon, and so on.

It is hoped that the "softened" use of public spaces through the implementation of quality landscaping alongside the tramway

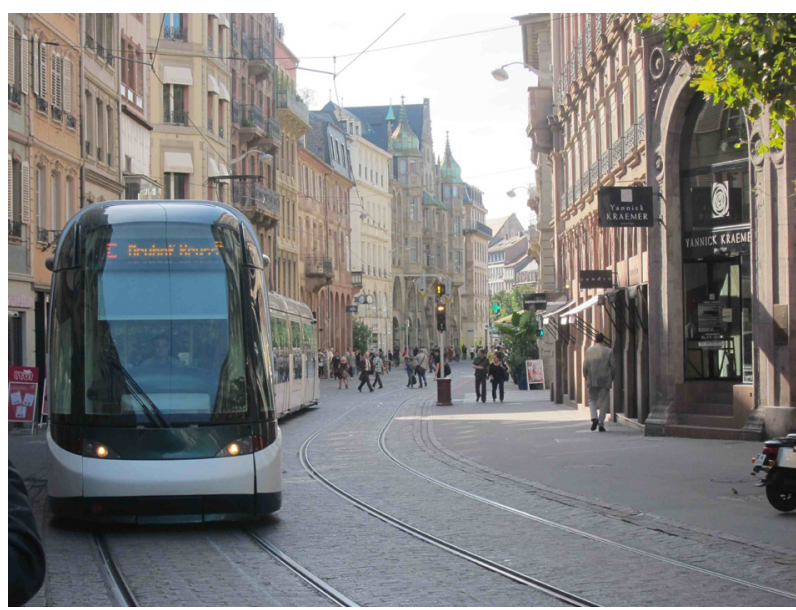

Figure 2. Tramway in the centre of Strasbourg (Author's photo)

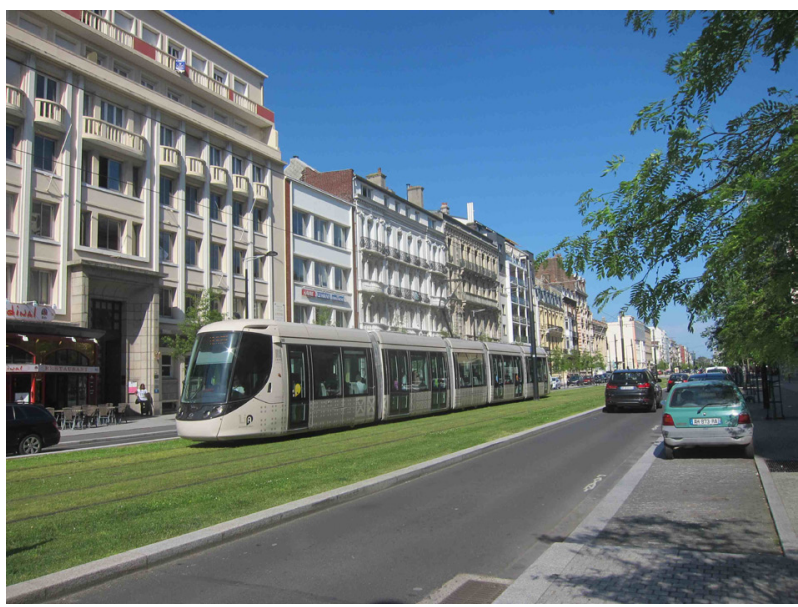

Figure 3. Tramway in le Havre (Author's photo)

lines will lead to increased pedestrian flow, increased safety and enhanced social interaction, which in turn will encourage visitors and tourists. Greenery and bike paths parallel to the tramway tracks are supposed to reintroduce nature and healthy lifestyles in the city. In Reims, the construction of the tram network was accompanied by the planting of 1,700 trees, 34,800 bushes and more than 80,000 square meters of lawns alongside the tracks, creating a new green corridor in the city.

\section{Trams as tools for the reordering of urban space}

Apart from the purely aesthetic dimension of the projects, what has made trams a success is the fact that they offer a good way to rethink urban space, and enhance the attractiveness of cities: design meets density and diversity (Cervero \& Kockelman 1997). Beyond the rehabilitation of the existing urban fabric alongside the tram routes, transportation projects can be an opportunity to support the development of the city (Offner 1993). The tram as it has developed in France cannot be reduced to a simple matter of transport. It is in fact a tool for urban change (Gonzalez et al. 2013, Konopacki-Maciuk 2014, Olesen \& Lassen 2016): reorganization of cities' polarities, rejuvenation of decaying neighbourhoods and sustainment of new developments and new business clusters, such as Dijon's northern end of Line 2 (Valmy). 
Trams have the virtue of concentrating resources and stakeholders around a shared project that can be a powerful catalyst for the transformation of the urban fabric, an instrument of urban requalification. Trams are a tool to regulate the role of the automobile in the city, by reducing the road space assigned to it in urban centres, and to encourage the reconstruction of public spaces, giving more room for pedestrians and bicycles. In Nice, the central Massena Square is now shared by pedestrians and trams only, after cars being removed from it. In Besançon, the pedestrian sector has been extended as work for the tramway progressed in the centre of the city. In Dijon, the advent of the trams has led to a reorganization of the entire system of buses and has freed the central city street, rue de la Liberté, from long lines of buses: the street has been turned into a pedestrian street and completely re-paved. Major streets in central Strasbourg have been closed to car traffic and reserved for pedestrians and trams. The tram service has also helped the upgrading of an old neighbourhood, Faubourg de Saverne, near the Strasbourg train station (Soto 2011), which has been remade into a city gate.

The tram can be considered a support element for a linear urbanism that may help to restructure cities by creating links between city centres and peripheral social housing areas, as in Orléans (La Source) (Archambault 1995), Montpellier (La Paillade), Reims (Orgeval), Mulhouse (Quartier des Coteaux) and Strasbourg (Hautepierre). In 2009, 30\% of the subsidies granted by the French government to communities for their rail projects were devoted to the service and requalification of these social housing neighbourhoods alongside tramway lines.

The extensions of the first tram lines built in large cities focused on areas remote from the centres and therefore less dense, as seen in Nantes (extensions of Lines 1 and 2), Grenoble (extension of Line D to Saint Martin d'Heres), and Lyon (extension of the T2 line to Saint-Priest). Extending a tram line to remote areas of central cities is a major bet for the urbanization of peripheral areas. The tramway project is an accelerator of urban projects. For example, T2 in Lyon has been very important for the municipality of Bron, which for many years had been trying to redevelop its town centre, without success. The arrival of the tramway in the heart of the town has been a real engine of growth and the line has had a positive impact on real estate development alongside Franklin Roosevelt Avenue.

Mulhouse has adopted the German idea of the tram-train (Desjardins 2011) on one of its lines, the only French city so far to push for this kind of inter-modality between urban rail and interurban rail, while Strasbourg is extending its network towards Germany (Beyer 2011).

Trams also allow the implementation of multipolar planning, organizing the city around its stations through the creation of intermodal nodes, the reorganization of traffic, the development of residential areas, shops and activities, and a reconnection with intercity traffic in train stations (see section below).

Urban development is to be organized around public transport routes, following the example of Montpellier (Le Tourneur 2010). In this city, the tramway has been the structural element of urban development over the last decade. Line 1 defines the central axis of the expansion of the town; Line 2 serves the urban development of low-density suburban territories; Line 3 supports the development of planning for new employment and housing areas. All academic institutions are served by the tram lines. The city, as part of the development of its "road to the sea", is working on Line 4, which will allow for the reorganization of shopping districts, the creation of a new housing and jobs cluster and the construction of the Ecocity planned for this area of Montpellier.

Tramway corridors are considered spines for future urban development, in order to limit urban sprawl which causes too much car traffic, and to ensure maximum use of the infrastructure.
A new tram line is not just a new element in the transport supply of an urban area, but it brings the possibility of powerful effects on the three environments of the city: economic, social and natural. The tramway line is envisioned as being the backbone of urban policies to foster a more sustainable city (Stambouli 2005, Blanquart et al. 2013). Tram development is therefore following the general principles of transit-oriented development (Cervero 1984, Rudolf and Hamman 2011), since urban planning tends to be reorganized around the tramway network.

In Le Mans, the arrival of the tramway allowed the launch of new real estate transactions along the line representing 1,500 housing units, the reaffirmation of the role of certain sectors, including the train station area and the university, and the exploration of new areas, such as the future cultural hub (Museum of History and Archaeology, City of music, dance and theatre).

In Dijon (see figure 4), an effort has been made to build tram links between all major nodes of activity and urban facilities (future high-speed rail station Porte Neuve, the stadium, Bocage Central university hospital, Erasmus university campus esplanade and Zenith entertainment and concert venues), and to develop new housing areas alongside the tram routes, especially the former military barracks now turned into "écoquartiers" (sustainable neighbourhoods) (Rouzaut 2007, Boquet 2010b, 2011). The city has done a lot to develop its tram network and the use of bicycles simultaneously (Joannis 2008). A common section of the tramway network lies between the train station (Gare) and a central square (Place de la République), while the tram depot is located on the southern side of the city, in Chenôve municipality, and connected to regular heavy rail tracks.

In Bordeaux (Marques 2002, Boutmy 2003), although Gaullist mayor and former Prime Minister Jacques Chaban-Delmas rejected the return of trams in the 1970s, his successor in 1995, Alain Juppé (same party, also a powerful national figure as Prime Minister under Jacques Chirac) is widely credited, even by his political opponents, for reviving both the tramways and the city. He had (and still has) the political clout to secure funds and push for projects. In this case, his objective was to respond to three major urban challenges: a) the impoverishment of formerly industrial districts on both sides of the Garonne river, particularly on the right bank, opposite the city centre; b) the population decline in the city centre, due to the appeal of suburban areas; c) the isolation of socially deprived areas, with mediocre bus services and ignored by the previous VAL plans for the city. The implementation of a tram network had three specific objectives in terms of urban revitalization: a) enhancing the architectural and urban heritage of the $17^{\text {th }}$ century city centre: tramways would free up space used by cars; b) reconnecting the Bastide neighbourhood on the Eastern side to the rest of the city; c) serving the needs of poor neighbourhoods and university students by connecting the periphery to the centre of town. The tramway system was not designed by railway engineers alone - Juppé assembled a team including landscape architects and designers. To limit the visual impact of tram catenaries, an untested system of trams drawing power from underground third rail power was trialled in the central part of the city, which proved difficult to manage. Success was immediate, and today tramways provide for $53 \%$ of all travel in the metropolitan area. In the future, there are hope for the creation of up to 50,000 housing units near the tramway lines in the Bordeaux area, in an effort to increase urban density alongside the main axes of transportation and limit urban sprawl into the vineyards or forests. This is clearly transitoriented development.

Trams for inter-modality and modal shift

Efforts have been clearly been made to facilitate intermodality and enhance the daily mobility chain of users. Train 


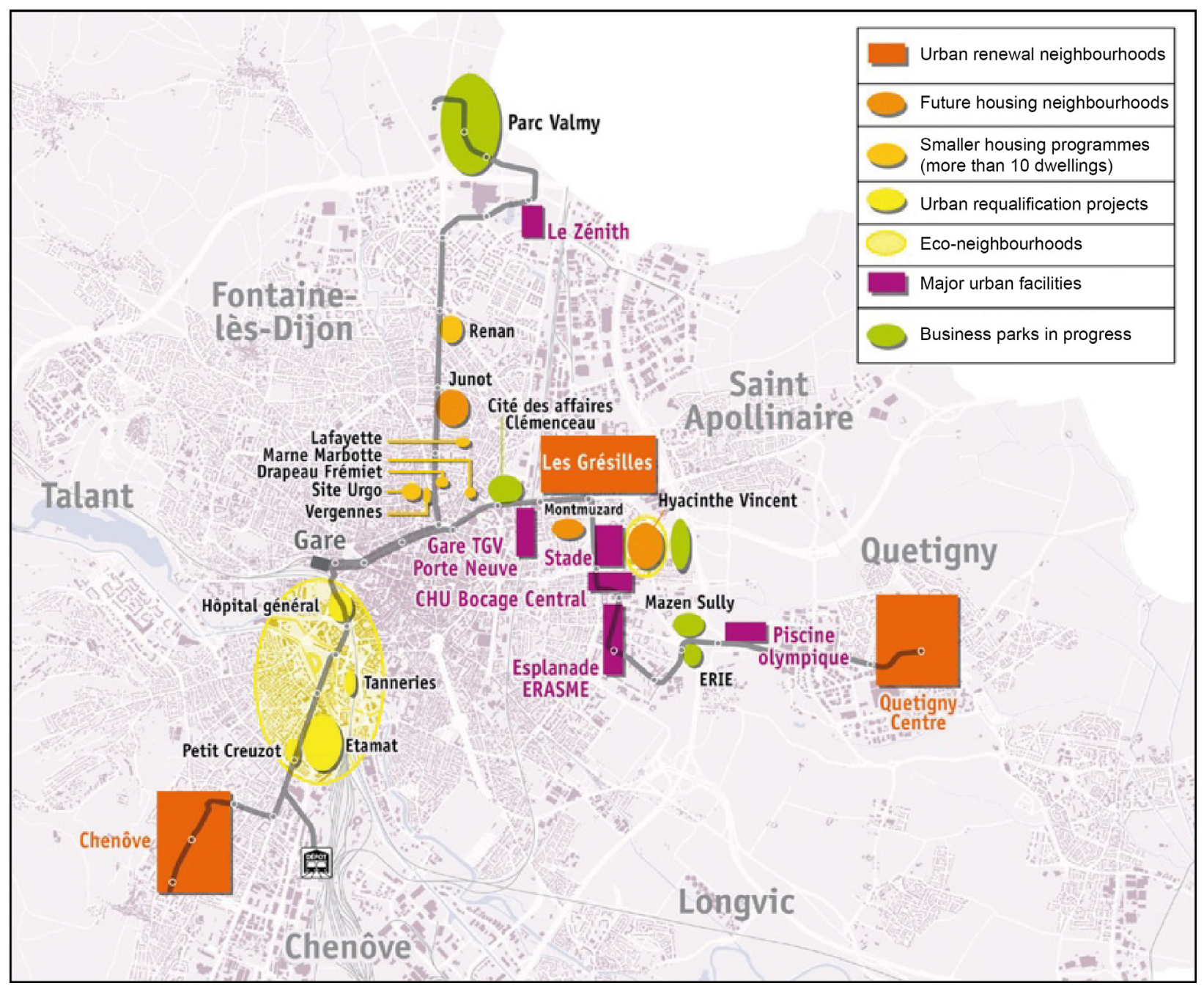

Figure 4. Tramway-oriented development in Dijon (source: Grand Dijon)

stations have been central in this regard, at a time when SNCF, through its "Gares \& Connexions" programme is trying to transform them into multi-use hubs (shops, restaurants) and not just a place to catch a train: tram lines often start a few steps from the train station exit, offering easy transfer from intercity to intracity transportation. Taxi stands and bike rental stands have taken the space formerly used by parking, which has lost more than half of the space it used to occupy in front of the stations, if not all the space. A number of cities have made the most of the opportunity of the arrival of high-speed train services to launch their tram systems and to make the city train station a major hub of transportation. However, city strategies may be thwarted by the efforts of SNCF to develop new train stations outside of the urban area ("gares-bis"). While Reims has linked both the central train station and the new TGV station with trams, this has not been the case in Besançon, where the tram serves Besançon Viotte, the main station, but not the new outlying TGV station Besançon-Franche-Comté.

Bus networks have been remodelled to fit with the tram: tramway lines have taken over successful bus routes, and the main role of the bus is now to feed the tram system from areas not covered by urban rail. In many cities, a two-level bus system has been implemented, with high frequency (5-7 minutes) and higher capacity buses (articulated buses) on a few routes which may in the future be converted into new tramway lines, and smaller buses with less frequent service (every 15-20 minutes) on other routes. During peak hours, trams on some lines run every 4 minutes, and when they share a common track in central areas, it means that the wait for a tram may be reduced to just 2 minutes, which is comparable to a high density underground metro system.

The implementation of tramway lines goes hand in hand with the development of mobility policies aimed at shifting away from car use and encouraging a greater use of public transport: new constraints on automobile traffic and parking are counterbalanced with the set-up of bicycle facilities, the development of enterprise mobility schemes, and the promotion of car-sharing and carpooling. Have trams contributed to a significant modal shift? In most medium-sized cities (below the level of Paris, Lyon, Lille, Marseille and Toulouse), trams are now dominant in terms of the number of public transit trips (Gagnière 2012). Data from the CERTU research centre shows that, in 2008, trams had a much larger share of passengers than the length of their network implied: $64 \%$ of trips in Strasbourg vs. $31 \%$ of public transit network length, $75 \%$ vs. $30 \%$ in Montpellier, $56 \%$ vs. $24 \%$ in Grenoble, and $59 \%$ vs. $20 \%$ in Nantes. Of course, the share in passenger transport is strongly influenced by the location of particular public 


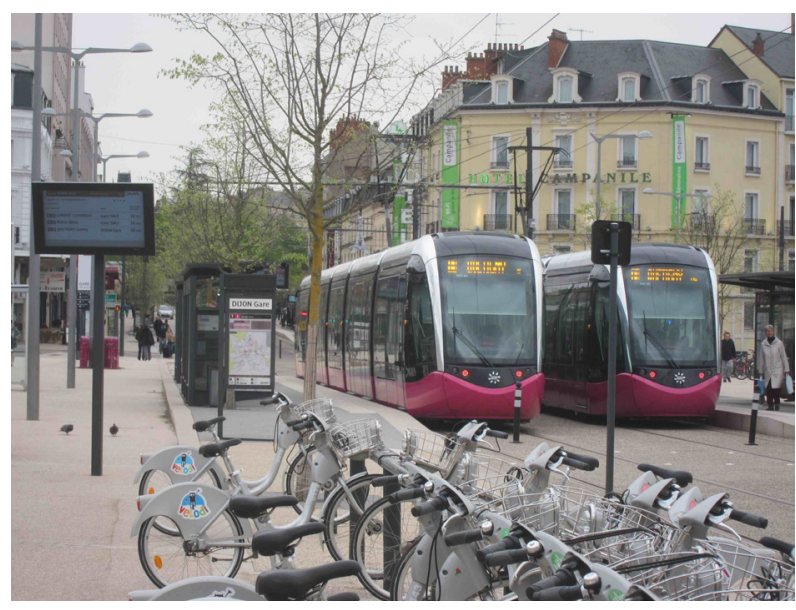

Figure 5. Tramway and bike rental stations in front of the Dijon train station (Author's photo)

transportation routes, their frequency of services, and the size of transport fleets. Most bus lines are characterized by a low frequency of services and the use of smaller vehicles, while many bus routes run through suburbs away from the city centre, even bringing passengers to the tramway lines. The choice of a TOD strategy focusing on investment along the tramway lines, which are already designed to serve traffic-generating places such as train stations, shopping areas, hospitals, stadiums and universities, can only increase the share of tramways in public transit ridership. However, this is not the case in the largest cities: their share was insignificant in Lyon, due to the prevalence of the subway (underground subway lines represented $13 \%$ of the total network and $48 \%$ of trips) and Lille (subway $34 \%$ and $62 \%$ ).

The data is not as clear when it comes to modal shift, since suburban sprawl leads people to use their cars more, even if they are offered a Park-and-Ride transfer point on the outskirts of the city, transforming their unimodal (car) trip into a bimodal one (car + tram).

Conclusion: Is tram the solution for transportation in French cities?

There is clearly a major change happening in the transportation system of French cities. Tramways have become the essential element, while buses now serve as feeders for the tramway lines. At the same time, cities try to redevelop around the tramway lines. There is therefore a dual purpose, in transportation and in urban renewal. Have the trams achieved the expected results in terms of traffic reduction and modal shift, or a cleaner and greener urban environment, and as tool for the transformation of the urban fabric? The answer may differ from city to city, depending, among other things, on their size: the tramway has a greater potential for being an urban transformer in Dijon than in Paris!

Critics have argued that tramways are a fad and may not be the ideal solution for urban transportation. Trams may not be as environmentally-friendly as they appear. Of course, they do not produce exhaust fumes, but they are still somewhat noisy, they vibrate, and catenaries are still unsightly in historical districts. They run on rails, which are manufactured in steel plants not known for a low environmental impact. Trolleybuses also use electrical energy, but have no rails, hence they are cheaper to build and less polluting overall (Hodgson et al. 2013). Dedicated right-of-way routes are not specific to trams (Heddebaut 2007). They can be a tool for quality bus services, as demonstrated in Curitiba, Brazil many years ago, and then by a growing number of BRT systems around the world. BRT use of road space is comparable to trams, with the added benefit of higher flexibility, since buses can enter and exit the BRT corridors at any time, which is impossible for trams, constrained by the presence of rails. In the event of a malfunction, the whole tramway line grinds to a halt, while buses can detour around the problem point.

So why are mayors so enamoured with tramways? Could it be that, similarly to the auto lobby of the 1930s, the railcar industry (Alsthom) has been very effective in persuading mayors to opt for trams and save the industry threatened by the deceleration of TGV development? Is tramway above all an image?

Is tramway an ecological symbol, while road transportation (including buses) represents a waste of resources (fossil fuels) and the emission of pollutants? The proposed introduction of electric buses with roof solar batteries may change the environmental image of buses in the future. Several cities, such as Dijon and Amiens, already run small electric vehicles in the narrow streets of their city centres, but they are not seen as a replacement for regular buses and even less so for tramways. Things may change soon in Paris, with the proposed introduction of such vehicles in 2018 along the River Seine, replacing bus line $n^{\circ} 72$.

Is the tramway an efficient solution for transport problems? Strasbourg had high hopes for a decrease in car traffic after a 1997 survey taken barely three years after the commissioning of the first tramway. Later surveys, however, have shown that for the whole urban area, there is clearly an increase in public transport usage, but without a decline in car traffic. An assessment covering a dozen cities (Gagnière 2012) confirms that the usage of public transport has increased since the introduction of trams, with wide variations between cities (Bordeaux being the city where the tram has been most successful, as well as Dijon, where the trams are overcrowded at peak hours on Line 1 going through the university campus), but there is no sign of a major modal shift from the automobile.

Public transport is the most efficient in terms of radial movements, especially in the city centre, where automobility has decreased significantly. However, suburb-to-suburb mobility is best realized in cars, and continued urban sprawl cannot be met by the tramway. A tram line alone, or even an elaborate tram network, cannot solve all traffic problems.

The success of trams in France is evident but remains fragile. The "all automobile" option still has many followers, who are contesting the displacement of cars by trams in city centres, deplore the duration of its construction and the disturbance it causes, and criticize the public money spent on unconvincing results (Darbera 2009). For proponents of walking and cycling PDUs, overemphasis on urban rail and the cost of tram construction limits the development of bike paths and safe pedestrian routes.

Even within the camp of public transport defenders, the tram may be criticized as being inadequate. In medium-sized cities, BRT may offer the same transport capacity at a much lower cost (Deutsch 2008). Nantes is now developing a busway (BRT) south of the River Loire. For larger cities, such as Paris, or even Lyon, trams do not offer enough capacity to solve traffic congestion (Prud'homme et al. 2011), and the money spent on beautiful tram lines would be better allocated to fund subway lines with a much higher passenger load.

However, if trams are considered in terms of their overall value as tools for city redevelopment, criticisms based mainly on their efficiency as transport instruments can be overcome. Comparing France with other European countries (Priemus \& Konings 2001, Desjardins et al. 2014, Zelezny 2014) may be a good way to assess the real value of tramways for French cities. It is noteworthy that the success of French trams has allowed the export of the concept to other countries, such as Algeria and Morocco. 
Allemand, S, Ascher, F \& Lévy 2005, Le sens du mouvement. Modernité et mobilités dans les sociétés urbaines contemporaines, Belin, Paris.

Archambault, MF 1995, 'Le tramway d'Orléans, vecteur d'urbanisme ?', Transports Urbains, no. 95, Avril-Juin, pp. 9-14.

Beyer, A 2011, 'L'enjeu transfrontalier de l'extension des réseaux de tramway urbain à Strasbourg et Bâle' in Le tramway dans la ville. Le projet urbain négocié à l'aune des déplacements, eds F Rudolf \& P Hamman, pp. 253-267, PUR, Rennes.

Blanquart, C, Héran, F \& Zéroual, T 2013, 'Les conditions de production d'un transport durable: nouvelles interventions publiques, nouveaux référentiels ?', Développement Durable et Territoires, vol. 4, no. 3. Available from: <http:// developpementdurable.revues.org/10066>. [29 December 2016].

Boquet, Y 2010a, 'The return of bicycles as a sustainable transportation tool in France' in Transportation and Urban Sustainability, Proceedings of the 15th Hong Kong Society for Transportation Studies conference eds A Sumalee, W Lam, H Ho \& B Siu, pp. 55-62, Hong Kong Polytechnic University, Hong Kong.

Boquet, Y 2010b, 'From PLUto Eco-PLU: strategies for a sustainable city in Dijon, France' in ICSU 2010, Proceedings of the 1st International Conference on Sustainable Urbanization ed JG Teng, pp. 1043-1051, Hong Kong Polytechnic University, Hong Kong.

Boquet, Y 2014, 'Transportation and sustainable development in a mid-size French city, Dijon', International Review for Spatial Planning and Sustainable Development (Kanazawa, Japan), vol. 2, no. 2, pp. 52-63.

Boutmy, E 2003, La mise en place d'un réseau intermodal de transports collectifs pour rééquilibrer l'agglomération bordelaise, Masters dissertation, Department of geography, Université Bordeaux III, Bordeaux.

Carmona, M 2001, Tramway, le coût d'une mode, Paradigme Edition, Orléans.

Cervero, R 1984, 'Light rail transit and urban development', Journal of the American Planning Association, vol. 5, no. 2, pp. 133-147.

Cervero, R \& Kockelman K 1997, 'Travel demand and the 3Ds : density, diversity and design', Transportation Research Part $D$, vol. 2, no. 3, pp. 199-219.

Darbera, R 2009, 'Le coût économique du report modal vers le tramway', Transports, no. 454, pp. 87-91.

Demongeot, B 2011, Discuter, politiser, imposer une solution d'action publique. L'exemple du tramway, Ph.D dissertation, Université de Grenoble, Grenoble.

Desjardins, X 2011, 'Quand le tramway sort de la ville. Réflexions sur la pertinence territoriale des tramways régionaux à partir de l'exemple de Kassel', Transports urbains, no. 119, pp. 16-22.

Desjardins, X, Maulat J \& Sykes, O 2014, 'Linking rail and urban development : reflections on French and British experience', Town Planning Review, vol. 85, no. 2, pp 143-153.

Deutsch, V 2008, 'Cost pointers for the implementation of tramway and bus systems', Public Transport International, vol. 57, no. 5, pp. 48-51.

Ferbrache, F \& Knowles, R 2016, 'Generating opportunities for city sustainability through investments in light rail systems: Introduction to the Special Section on light rail and urban sustainability', Journal of Transport Geography, vol. 54, pp. 369-372.
Freemark, Y 2012, 'Commitment to Tramways Makes France a World Model for New Urban Rail', The Transport Politic, 24 June 2012. Available from: <http://www.thetransportpolitic. com/2012/06/24/commitment-to-tramways-makes-france-aworld-model-for-new-urban-rail/>. [29 December 2016].

Frère, S, Menerault, P \& Roussel, I 2000, 'PDU et dynamique des institutions à Lille et à Valenciennes', Recherche-TransportsSécurité, vol. 69, pp. 22-34.

Gagnière, V 2012, 'Les effets du tramway sur la fréquentation du transport public. Un bilan des agglomérations françaises de province', Revue Géographique de l'Est, vol. 52, no. 1-2. Available from: <http://rge.revues.org/3508>. [29 December 2016].

Gonzalez, RL, Oton, MP \& Wolff, JP 2013, 'Le tramway entre politique de transport et outil de réhabilitation urbanistique dans quelques pays européens: Allemagne, Espagne, France et Suisse', Annales de Géographie, no. 2013-6, pp. 619-643.

Groneck, C 2007, Französische planungsleitbilder für straßenbahnsysteme im vergleich zu Deutschland, Ph.D. dissertation, Bergischen Universität, Wuppertal.

Heddebaut, O 2007, 'Les difficultés de mise en oeuvre des sites propres pour les modes de transport collectifs guidés ou non. Le cas des lignes de bus à haut niveau de service', Recherche Transports Sécurité, no. 94, pp. 27-45.

Héran, F 2009, 'Des distances à vol d'oiseau aux distances réelles ou de l'origine des détours', Flux, no. 76-77, pp. 110-121.

Héran, F 2014, Le retour de la bicyclette. Une histoire des déplacements urbains en Europe de 1817 à 2050, La Découverte, Paris.

Hodgson, P, Potter, S, Warren, J \& Gillingwater, D 2013, 'Can bus really be the new tram ?', Research in Transportation Economics, vol 39, no. 1, pp. 158-166.

Joannis, C 2008, Les relations d'acteurs dans le cadre d'une concertation d'aménagement urbain. L'exemple du schéma directeur en faveur des cyclistes dans l'agglomération dijonnaise, Masters dissertation, Department of geography, Université de Bourgogne, Dijon.

Konopacki-Maciuk, Z 2014, 'Trams as tools of urban transformation in French cities', Technical Transformations / Architecture, no. 10-A, pp. 61-79.

Laisney, F 2001, 'Espaces publics : une culture de la résistance à l'automobile', Géocarrefour, vol. 76, no. 1, pp. 39-45.

Larroque, D 1989, 'Apogée, déclin et relance du tramway en France', Culture Technique, no. 19, pp. 54-63.

Larroque, D 1990, 'L'expansion des tramways urbains en France avant la Première Guerre Mondiale', Histoire, Économie et Société, vol. 9, no. 1, pp. 135-168.

Le Tourneur, M 2010, 'The integration of urban planning and transport in montpellier', Public Transport International, vol. 59 , no. 5, pp. 8-9.

Marconis, R 1997, 'Métros, V.A.L., Tramways... La réorganisation des transports collectifs dans les grandes agglomérations de province en France', Annales de Géographie, no. 593594, pp. 129-154.

Marques, C 2002, Le tramway facteur de revitalisation de l'espace public à Bordeaux cas de la ligne B, DEA dissertation, Department of geography, Université Bordeaux III, Bordeaux.

Mercier, A 2008, Accessibilité et Évaluation des Politiques de Transport en Milieu Urbain: le Cas du Tramway 
Strasbourgeois, PhD dissertation, Faculté de Sciences Économiques et de gestion, Lyon.

Millet, A 2008, Comment replacer les piétons au cśur des mobilités ? L'exemple du PDU de Montpellier, Masters Thesis, ENTPE, Lyon.

Mills, G 2001, 'New tramways in France: The case of Montpellier', Transport Reviews: A Transnational Transdisciplinary Journal, vol. 21, no. 3, pp. 337-352.

Muller, G 2000, Génération Tram, Oberlin, Strasbourg.

Offner, JM 1988, 'La disparition des tramways en France', La Revue des Chemins de fer, no. 388, pp. 6-10.

Offner, JM 1993, 'Les effets « structurants » du transport: mythe politique, mystification scientifique', L'Espace Géographique, no. 3, pp. 233-242.

Offner, JM, Menerault, P \& Sachet, S 2002, 'Les transports urbains : entre secteurs, réseaux et territoires', Annuaire des Collectivités Locales, no. 22, pp. 169-183.

O'Toole, R 2012, 'The great streetcar conspiracy', Policy Analysis, no. 699 , June 14,2012 , p. 20. Available from: <http://www.cato.org/sites/cato.org/files/pubs/pdf/PA699. pdf>. [29 December 2016]

Olesen, M \& Classen, C 2016, 'Rationalities and materialities of light rail scapes', Journal of Transport Geography, vol. 54, pp. 373-382.

Peyon, JP 2003, 'Le tramway à Nantes: renouveau technique, pari politique et nouvelle image territoriale', Cahiers Nantais, no. 60 , pp. 87-93.

Priemus, H \& Konings, R 2001, 'Light rail in urban regions: what Dutch policymakers could learn from experiences in France, Germany and Japan', Journal of Transport Geography, vol. 9, no. 3, pp. 187-198.

Prud'homme, R, Koning, M \& Kopp, P 2008, 'Paris, un tramway nommé désir', Transports, no. 447, pp. 28-39.

Prud'homme, R, Koning, M \& Kopp, P 2011, 'Substituing a tramway to a bus line in Paris: costs and benefits', Transport Policy, vol. 18 , no. 4, pp. 563-572.

Rabuel, S 2009, 'Tramway et Bus à Haut Niveau de Service (BHNS) en France: domaines de pertinence en zone urbaine', TEC Mobilités Intelligentes, no. 203, pp. 63-71.

Redondo, B 2012, ' Tramway et territoire : quel urbain en perspective ?', Revue Géographique de l'Est, vol. 52, no. 1-2. Available from: <http://rge.revues.org/3572>. [29 December 2016].

Redondo, B 2015, 'Le projet partenarial art public/tramway : pour quel(s) récit(s) de ville ?', Articulo Journal of Urban Research, no. 7. Available from: < https://articulo.revues. org/2757>. [16 February 2017].
Rouzaut, E 2007, Les friches militaires à travers l'exemple de Dijon, Masters dissertation, Department of geography, Université de Bourgogne, Dijon.

Rudolf, F \& Hamman, P (eds) 2011, Le tramway dans la ville : Le projet urbain négocié à l'aune des déplacements, PUR, Rennes.

Snell, B 2001, The street car conspiracy. How General Motors deliberately destroyed public transit. Available from: <http:// www.whale.to/b/street_car_conspiracy.html>. [29 December 2016].

Soto, M 2011, 'La mise en valeur de la proximité et du passage dans les dimensions urbaines globales/locales: le cas de tramway C au Faubourg de Saverne à Strasbourg' in Le tramway dans la ville. Le projet urbain négocié à l'aune des déplacements eds F Rudolf \& P Hamman, pp. 231-251, PUR, Rennes.

Stambouli, J 2005, 'Les territoires du tramway moderne : de la ligne à la ville durable', Développement Durable et Territoires, Dossier 4: La ville et l'enjeu du Développement Durable. Available from: <https://developpementdurable. revues.org/3579>. [29 December 2016].

Tira, M \& Yerpez J 2002, 'Les plans de déplacements urbains français (PDU) et les plans urbains de trafic italiens (PUT) au-delà des différences de procédure', Méditerranée, no. 98, pp. 91-96.

Wilkins, V 1995, 'The conspiracy revisited', The New Electry Railway Journal, Summer 1995, pp. 19-22.

Wolff, JP 2012, 'Le tramway : au coeur des enjeux de gouvernance entre mobilité et territoires', Revue Géographique de l'Est, vol. 52, no. 1-2, Available from: <http://rge.revues. org/3498>. [29 December 2016].

Yerpez, J (ed) 1995, Le plan de déplacements urbains, un processus sous le regard des chercheurs, IFSTTAR, Marnela-Vallée.

Zelezny, R 2014, 'Tramway-oriented development: what results in what context? Comparative approach between France and the Czech Republic', Transportation Research Arena (TRA) 2014, Apr 2014, Paris - La Défense. Available from: <https://hal.archives-ouvertes.fr/hal-00871264v2>. [29 December 2016]

Zembri, P 2012, 'La conception des transports collectifs en site propre (TCSP) en France: des tracés problématiques' Revue Géographique de l'Est, vol. 52, no. 1-2, Available from: <http://rge.revues.org/3603>. [29 December 2016]. 